\title{
THE ADJECTIVAL GROUP IN THE ENGLISH CHANCERY DOCUMENTS
}

\author{
María Jesús Pérez Quintero \\ Universidad de La Laguna
}

\begin{abstract}
Historical Linguistics has been mainly concerned with the study of the word, both from the point of view of its phonological and morphological structure and from the perspective of its etymology, all this to the detriment of the study of syntax. Even though some works about mediaeval syntax have dealt with the different parts of speech as linguistic categories, little attention has been paid to the syntagmatic structure of the different clause constituents. The syntactic study of the English Chancery documents has been similarly overlooked, despite their importance for the development of standard Modern English. This article is devoted to the study of the Adjectival Group in the Chancery documentary texts, in order to, on the one hand, arrive at a better knowledge of the syntactic structure of this linguistic category and, on the other, to see to what extent these texts have contributed to the development of standard Modern English.
\end{abstract}

RESUMEN. La lingüística histórica se ha centrado principalmente en el estudio de la palabra, tanto desde el punto de vista morfo-fonológico como desde la perspectiva etimológica, todo ello en detrimento de los estudios de sintaxis. Aunque algunos trabajos sobre sintaxis medieval abordan el estudio de las partes de la oración como categorías lingüísticas, se ha prestado poca atención a la estructura sintagmática de los distintos constituyentes de la cláusula. La estructura sintáctica de los documentos de la cancillería inglesa ha recibido igualmente escasa atención, a pesar de la importancia de los mismos para el desarrollo del inglés moderno estándar. Este artículo aborda el estudio del sintagma adjetival en los textos documentales de la cancillería, con el fin de, por una parte, llegar a un mejor entendimiento de la estructura sintagmática de esta categoría lingüística y, por otra parte, comprobar hasta que punto estos textos han contribuido al desarrollo del inglés moderno estándar.

\section{Introduction}

The early English Chancery documentary texts in the vernacular, despite their importance for the development of Modern Standard English, have not so far been subject to much grammatical scrutiny. In general, the attention paid to those documents has concentrated, more or less systematically, on their phonological and morphological make-up in an attempt to determine their role in relation to the 
emergence of the modern standard language. Thus, Morsbach (1888) and Lekebusch (1906) included a collection of parliamentary and official records in their analysis of the origins and development of the modern English Schriftsprache. More recently, Samuels (1963) and Fisher (1977) have in the same vein commented on some formal characteristics of Chancery English. With varying emphasis, these and other contributions have shown the importance of the royal chancery in the normalisation (and thus in the standardisation) of the vernacular language. But, given the now general acceptance of Chancery English as the forerunner of Modern Standard English, ${ }^{1}$ it is surprising that the grammar of that noteworthy linguistic variety has not attracted the research it deserves. Only lately has this gap begun to be filled (Pérez Quintero 1994, Expósito González 1996). This article seeks to contribute to a better understanding of the structure of the adjectival group in Late Middle English and, at the same time, to a better knowledge of the syntactic structures of Chancery English. In particular, I will first examine the inflectional properties of adjectives (section 2) and, later, I will provide a description of the syntactic structures of adjectival groups (section 3).

The corpus edition that has been used in this study is the one offered by Fisher, Richardson and Fisher (1984). ${ }^{2}$ These authors follow Samuels:

in calling the official written English of the first half of the $15^{\text {th }}$ century "Chancery English" although it emanated from at least four offices, Signet, Privy Seal, Parliament, and the emerging Court of Chancery itself (1984: xii).

Due to this variety, the texts that constitute this anthology are arranged in four different groups: (i) Signet (S), including 105 texts belonging to the Signet of Henry V (1417-1422) and four belonging to the Later Signet Letters (1434-1455); (ii) Privy Seal Papers (P), 51 texts written between 1408 and 1455; (iii) Proceedings of Parliament and Chancery (C), containing 72 petitions presented to the Parliament and actions upon these petitions (1388-1455); (iv) Indentures $(\mathrm{N})$, constituted just by nine texts written between 1384 and 1462 .

The period under analysis is the one that extends from 1400 to 1450 because it is considered to be the most representative one ${ }^{3}$ as far as the establishment of the standard Chancery English conventions is concerned. 4

1. In this respect we follow the position held by Samuels (1972; 1981), Hughes (1980) or Richardson 1980; 1984), although not free of controversy (cf. Fisher 1977; 1979).

2. The texts have been transcribed form the originals that are found in the Public Record Office and in the British Library. This is a reliable edition since the purpose has been "to represent as exactly as feasible in computer composition the texture of written English in official documents" (Fisher, Richardson and Fisher 1984: 79).

3. Cf. Expósito González (1996: 57-9) for a discussion of the representative size of a corpus of data.

4. In the examples provided in this article, $\mathbf{0}$ stands for the period 1400-1409 (1 text), $\mathbf{1}$ stands for 1410-1419 (78 texts), 2 for 1420-1429 (60 texts), 3 for 1430-1439 (58 texts) and 4 for 1440-1450 (25 texts). 


\section{Adjective Inflection}

Previous analyses of adjective morphology in Chancery documents have been cursory and impressionistic. Morsbach (1888) paid attention to the distinction between the strong and weak inflections of adjectives, and to their plural variants. More directly relevant for our purpose in this paper are the paragraphs included by Fisher, Richardson and Fisher (1984) in the introduction to the edition used as the basis for this research. Here they mention that adjectives are not usually inflected in the Chancery documents, except in formulae adapted from French. Brief reference is also made to the plural inflection of some adjectives and to the alternative positions they adopt when inflected. Nevertheless, there is neither an indication of the frequency of the different positions nor of the number of adjectives inflected for number in relation to those that follow the Modern English pattern. Furthermore, no consistent distinction is made between the open and closed classes of adjectives. It is also important to notice that in the glossary of forms at the end of the book some categorisation problems can be found as, for instance, in the case of right, which is classified as an adjective, or in the case of trusty, behoueful or necessary, which are considered adverbs. Incomplete as it is, the information provided by Fisher, Richardson and Fisher is, however, quite valuable.

This section seeks to be a contribution to the study of the adjective as a lexical category of the open class (Quirk et al. 1991: 67). This discussion of adjectival inflection will centre around two main aspects: a description of the declension system (2.1) and an analysis of the synthetic gradation of adjectives (2.2).5 As far as the declension system is concerned, two main points will be taken into consideration: the existence of relics from the old weak/strong declension (2.1.1) and of examples of inflection for number (2.1.2).

\subsection{Declension system}

\subsubsection{Final -e inflection}

One of the most characteristic features of the Germanic languages was the development of a double declension of the adjective. In Old English, adjectives were inflected for case, gender and number. Two types of declension were distinguished, the strong and the weak declensions. In the course of the Middle English period, adjectives ceased to be inflected, except for monosyllabic adjectives ending in a consonant, which took a final $-e$ in the singular forms of the weak declension as well as in the plural forms of both declensions, the weak and the strong one. Many authors, Mustanoja (1960: 276) among them, point out that, even though the - $e$ / $-\varnothing$ opposition is observed by some fourteenth century writers, in early Middle English texts there is

5. The analytic gradation of the adjective is studied in section 3, as part of the adjectival modification and complementation. 
an important degree of indeterminacy in the use of the weak and strong declensions. If this distinction is still productive in the period under analysis here, monosyllabic adjectives of consonantal root should exhibit for the singular a variation between $-\varnothing$ and $-e$ depending on their occurrence in a non-defining (strong: $-\varnothing$ ) or defining (weak: -e) context.

In the English Chancery documents, some adjectives take a final $-e$ for the singular as well as for the plural. It seems to be interesting to pay attention to the monosyllabic ones ending in a consonant in order to see if they conform to the distinction $-\varnothing /-e$ found in several fourteenth century writers. Table 1 offers the statistical distribution of the different monosyllabic adjectives ending in a consonant according to the context in which they take final $-e$ or $-\varnothing$. The first two columns offer the forms with or without final $-e$ adopted by adjectives occurring in a syntactic context that in Old English would have required the weak declension. The two middle columns present $\pm e$ variants of adjectives in the position typical of the strong declension. Finally, the two last columns display the plural forms ending in $-e$ or $-\emptyset$, without attention being paid to the type of context, since the weak / strong distinction is not relevant for the plural. ${ }^{6}$

6. The selection of the adjectives was carried out making use of the glossary offered by Fisher, Richardson and Fisher (1984), where all forms of each word in the corpus are listed. 
THE ADJECTIVAL GROUP IN THE ENGLISH CHANCERY DOCUMENTS

\begin{tabular}{|c|c|c|c|c|c|c|}
\hline Adjectives & Sg.W. -e & Sg. W. $-\varnothing$ & Sg. St. -e & Sg. St. $-\varnothing$ & Pl. W+St.-e & PI.W+St.- \\
\hline ded(e) & - & - & 3 & 1 & 2 & - \\
\hline deed & - & - & - & 1 & - & - \\
\hline dredd(e) & 1 & - & - & 1 & - & - \\
\hline gladd(e) & 1 & - & 1 & - & - & - \\
\hline goodle) & 16 & 29 & 2 & 19 & 1 & 2 \\
\hline gode & 8 & - & 4 & - & 5 & - \\
\hline $\operatorname{gret}(e)$ & 72 & 17 & 39 & 14 & 23 & 3 \\
\hline greet(e) & 1 & 31 & 2 & 3 & - & 5 \\
\hline harde & - & - & - & - & 1 & - \\
\hline high(e) & 3 & 29 & - & 6 & 1 & 5 \\
\hline hole & 7 & - & - & - & - & - \\
\hline hool & - & 1 & - & 1 & - & 1 \\
\hline ilust(e) & - & - & 3 & 1 & - & - \\
\hline lastle) & 3 & 10 & - & 1 & - & - \\
\hline $\operatorname{lag}(e)$ & 2 & 1 & - & - & - & - \\
\hline long(e) & 5 & 6 & 3 & 7 & 1 & - \\
\hline meane & 1 & - & - & - & - & - \\
\hline meke & 1 & - & - & - & - & - \\
\hline mene & 1 & - & - & - & - & - \\
\hline new (e) & 3 & 3 & 1 & - & - & - \\
\hline$n e x t(e)$ & 1 & 17 & - & 9 & - & - \\
\hline old(e) & 6 & - & 5 & 2 & - & - \\
\hline jlein(e) & 2 & 3 & 1 & 3 & - & - \\
\hline poorte) & 13 & 1 & - & - & 18 & - \\
\hline riche & 1 & - & - & - & 1 & - \\
\hline roial(e) & 4 & 10 & - & - & - & - \\
\hline suffe) & 1 & 1 & 1 & 1 & - & - \\
\hline scuufie) & 14 & 7 & - & 1 & 2 & - \\
\hline sciff & - & 1 & - & 1 & - & - \\
\hline sciatf & - & 1 & - & 1 & - & - \\
\hline seke & 1 & - & - & - & - & - \\
\hline short(e) & - & - & 1 & 5 & - & - \\
\hline strange & - & - & - & - & 3 & - \\
\hline stronge & - & - & 1 & 3 & - & - \\
\hline taill(e) & - & - & 1 & 2 & - & - \\
\hline trew(e) & 5 & 1 & 9 & - & 25 & - \\
\hline roid(e) & 3 & 1 & 2 & - & 4 & - \\
\hline wilde & - & - & - & - & 1 & - \\
\hline longe & 1 & - & - & - & 2 & - \\
\hline Total & 177 & 170 & 79 & 83 & 90 & 16 \\
\hline
\end{tabular}

Table 1: Distribution of monosyllabic adjectives ending in a consonant 
The total number of uses and the percentages related to the use of $-e$ or $-\varnothing$ in the adjectives collected in Table 1 can be seen in Tables 2 and 3:

\begin{tabular}{|l|c|c|c|}
\hline Adjective & Weak & Strong & Total \\
\hline$-e$ & 177 & 79 & 256 \\
& $69.14 \%$ & $30.85 \%$ & $100 \%$ \\
\hline$-\varnothing$ & 170 & 83 & 253 \\
& $67.19 \%$ & $32.8 \%$ & $100 \%$ \\
\hline Total & 347 & 162 & 509 \\
& $68.17 \%$ & $31.82 \%$ & $100 \%$ \\
\hline
\end{tabular}

\begin{tabular}{|c|}
\hline Plural \\
\hline 90 \\
\hline 16 \\
\hline 106 \\
\hline
\end{tabular}

Table 2: Percentages of the $-e /-\varnothing$ ending

\begin{tabular}{|l|c|c|c|}
\hline Adjective & $-e$ & -0 & Total \\
\hline Weak & 177 & 170 & 347 \\
& $51 \%$ & $48.99 \%$ & $100 \%$ \\
\hline Strong & 79 & 83 & 162 \\
& $48.76 \%$ & $51.23 \%$ & $100 \%$ \\
\hline Total & 256 & 253 & 509 \\
& $50.29 \%$ & $49.7 \%$ & $100 \%$ \\
\hline
\end{tabular}

Table 3: Percentages of the $-e /-\varnothing$ ending

As a conclusion from the figures in Table 2, it can be argued that there is no regularity in the use of the ending - $e$. Even though it appears in one hundred and seventy seven instances of the singular weak declension $(69.14 \%)$ and in ninety of the plural, seventy-nine occurrences $(30.85 \%)$ are also found for the singular strong declension. Furthermore, these monosyllabic adjectives do not take any ending in eighty-three cases of the singular strong declension $(32.8 \%)$, but there is no inflection either in one hundred and seventy instances of weak declension and in sixteen plural examples. Likewise, as it is shown in Table 3 , in a defining context, the frequency of occurrence of the $-e$ ending is scarcely higher $(51 \%)$ than that of the $-\varnothing$ ending $(48.99 \%)$. In the same way, there is a certain degree of uniformity in the use of $-e$ or $-\varnothing$ in non-defining contexts $(48.76 \%$ in $-e / 51.23 \%$ in $-\varnothing)$. Therefore, it can be claimed that the distinction $-e /-\varnothing$ does not conform to a fixed pattern in the English Chancery texts.

Apart from considering the final $-e$ a relic from the old declension system, this ending can also be related to the old practice of adding a final $-e$ to a word in order to show that the stem vowel was long. In that respect, if attention is paid to the monosyllabic adjectives with two different spellings, it can be noticed that the use of this ending is more frequent in the forms with a simple vowel, although it can also be 
found in some cases in which there is a double vowel. Table 4 offers the data related to the use of the $-e$ ending in the following pairs of adjectives:

\begin{tabular}{|c|c|}
\hline $\begin{array}{l}-e \text { ending } \\
-\varnothing \text { ending }\end{array}$ & $\begin{array}{c}\text { ded }(e) / \text { deed } \\
5 / 0 \\
1 / 1\end{array}$ \\
\hline $\begin{array}{l}-e \text { ending } \\
-\varnothing \text { ending }\end{array}$ & $\begin{array}{c}\text { gode / good(e) } \\
17 / 19 \\
0 / 50\end{array}$ \\
\hline $\begin{array}{l}-e \text { ending } \\
-\varnothing \text { ending }\end{array}$ & $\begin{array}{c}\text { gret(e) / greet(e) } \\
134 / 3 \\
34 / 38\end{array}$ \\
\hline $\begin{array}{l}-e \text { ending } \\
-\varnothing \text { ending }\end{array}$ & $\begin{array}{c}\text { hole / hool } \\
7 / 0 \\
0 / 3 \\
\end{array}$ \\
\hline $\begin{array}{l}-e \text { ending } \\
-\phi \text { ending }\end{array}$ & $\begin{array}{c}\text { saf(e) / sacif } \\
2 / 0 \\
2 / 2\end{array}$ \\
\hline
\end{tabular}

Table 4: Distribution of the $-e$ ending in monosyllabic adjectives with two spellings

The conclusion that emerges from the previous analysis is that the presence or absence of final $-e$ in monosyllabic adjectives ending in a consonant is not determined by the syntactic context. Moreover, the use of final $-e$ is not exclusive to monosyllabic adjectives, but it is found in other adjectives such as habundant(e), $\operatorname{certain}(e)$, desolat(e), gracious(e), sufficient(e), temporel(e), willful(le), etc.

\subsubsection{Number inflection}

As has already been mentioned, the Middle English period is characterised by a drastic reduction of the complex adjective inflection system typical of Old English. Nevertheless, in late Middle English a new plural form seems to emerge favoured by French influence. This plural form was characterised by the addition of $-s$ to those adjectives postmodifying a noun, and less frequently to premodifying adjectives or to adjectives realising a predicative function. This type of construction, considered by Lass (1992: 116) typical of fifteenth- and sixteenth-century scientific, ecclesiastic and legal language, can be found in the English Chancery documents. Twenty adjectives, out of one hundred and nineteen that modify a plural noun, exhibit an inflectional change. These adjectives are alien, certain, couenable, diligent, diuers, excoutories, general, gracious, lawfull, necesarie, patent, personneles, retournable, seculer, seueral, spirituel, sufficient, temporell, triable and wise. These adjectives inflected for plural are mostly of French origin, except for necessarie, patent and temporell, which are loanwords from Latin, and lawfull and wise, of native origin. In most of the cases 
these adjectives postmodify the noun following the word order typical of French adjectives: Priouries and possesions Aliens / in vitailles couenables / his mareschalx and lieutenant 3 gen $<$ er $>$ alx, etc. However, these postmodifying adjectives can also be found uninflected: the saide $m<$ ar $>$ chant 3 alien / $l<e t t>$ res patente / your lordes $s p<$ irit>uell and temporell. In addition, it is important to notice that some premodifying adjectives are also inflected for number as, for example, in on $c<e r>$ teins endent $<u r>s$. As for the occurrence of adjectives in predicative function, it can be observed that only four of these adjectives (certain, couenable, necessary and sufficient) are found in this position where they are not inflected for plural. In the analysed documents there are one hundred and nine instances of adjectives in predicative function in a singular context and seventy-eight in a plural context, where the adjectives take the $-\varnothing$ ending. Adjectives inflected for number take, apart from the ending typical of present-day English, the following forms: $-3,-x$ and $-i$ s. Table 5 offers the distribution of the twenty adjectives that exhibit number inflection in attributive function:

\begin{tabular}{|l|c|c|c|c|}
\hline Adjectives & Pre. $-\varnothing$ & Pre. $-s$ & Post. $-\varnothing$ & Post. -s \\
\hline alien & - & - & 1 & 3 \\
certain & 55 & 2 & - & - \\
couenable & - & - & 1 & 1 \\
diligent & - & - & - & 1 \\
diuers & 45 & 7 & - & - \\
excoutories & - & - & - & 1 \\
general & 3 & - & - & 2 \\
gracious & 32 & 2 & - & - \\
lanfull & - & - & - & 1 \\
necessisire & - & - & 2 & 1 \\
patent & - & - & 1 & 82 \\
personneles & - & - & - & 1 \\
retournable & - & - & - & 1 \\
seculer & 1 & - & 1 & 1 \\
seueral & 1 & 1 & 1 & 1 \\
spirituel & 1 & - & 14 & 8 \\
sufficient & 2 & - & 1 & 1 \\
temporell & - & - & 15 & 9 \\
triable & - & - & 1 & 1 \\
wise & 26 & 1 & - & - \\
\hline Total & 166 & 13 & 38 & 115 \\
\hline
\end{tabular}

Table 5: Distribution of adjectives with number inflection in attributive function

Table 5 shows that, from the one hundred and twenty eight examples of inflected adjectives, only in thirteen occasions they premodify the noun. Similarly, uninflected adjectives adopt a prenominal position in one hundred and sixty six cases, out of two 
hundred and four instances of uninflected adjectives. From all this it follows that the most frequent construction is that in which the adjective is placed before the noun without adopting any plural mark, which coincides with the Modern English pattern. It can also be argued that in postposition the inflected forms prevail over the uninflected ones, as shown in Tables 6 and 7.

\begin{tabular}{|l|c|c|c|}
\hline Plural adj. & Preposed & Postposed & Total \\
\hline$-\varnothing$ & 166 & 38 & 204 \\
& $81.4 \%$ & $18.6 \%$ & $100 \%$ \\
\hline-5 & 13 & 115 & 128 \\
& $10.15 \%$ & $89.84 \%$ & $100 \%$ \\
\hline Total & 179 & 153 & 332 \\
& $53.91 \%$ & $46.08 \%$ & $100 \%$ \\
\hline
\end{tabular}

Table 6: Percentages of adjectival number inflection

\begin{tabular}{|l|c|c|c|}
\hline Plural adj. & $-\varnothing$ & $-s$ & Total \\
\hline Preposed & 166 & 13 & 179 \\
& $92.73 \%$ & $7.26 \%$ & $100 \%$ \\
\hline Postposed & 38 & 115 & 153 \\
& $24.83 \%$ & $75.16 \%$ & $100 \%$ \\
\hline Total & 204 & 128 & 332 \\
& $61.44 \%$ & $38.55 \%$ & $100 \%$ \\
\hline
\end{tabular}

Table 7: Percentages of adjectival number inflection

Furthermore, if attention is paid to the distribution of adjectives in a singular or plural context, it can be observed that those adjectives that occur in a singular or plural context with $-\varnothing$ ending favour preposition, whereas they exhibit a tendency towards postposition when they take the $-s$ as a mark for the plural. Likewise, this use of the plural forms in postposition is found in the different offices and periods, except in Indentures and in the period from 1400-1409, where there is no example of postposition, and in the period from 1420 to 1429 , where there are seven instances of inflected adjectives in preposition contrasting with six examples in postposition. The absence of postposed examples, in the singular as well as in the plural, in the Indentures documents and in the period from 1400 to 1409 must be due to the fact that the number of documents belonging to these two groups is quite limited.

The preceding data demonstrate that the use of the plural construction is not a generalised practice in the Chancery documents, since the same adjectives that adopt the plural inflection also occur in the same context without any plural mark. The most 
common construction is that in which a plural noun is preceded by an uninflected adjective that modifies it.

\subsection{Synthetic gradation}

There are many authors (Poutsma 1914; Kruisinga 1932; Curme 1980; Jespersen 1961-70; Quirk et al. 1991) that agree in distinguishing a synthetic (affixal) gradation and an analytic or periphrastic (more/most + adjective) gradation. Nevertheless, there is no agreement when they come to point out the features that determine the use of one or the other form of gradation. Poutsma (1914: 474) comments on the fact that during a period of time these two forms of grading the adjective were indiscriminately used, but that nowadays the use is determined by different factors such as euphony, rhythm, suitability, diction and, in a way, by the meaning. However, Kruisinga (1932: 64) states that the use of grading suffixes is not determined by the number of syllables, as it has been traditionally believed, but by the position of the main stress. He considers that the use of one or the other form of gradation is determined by phonetic structure as well as by syntactic function (attributive or predicative) and for emphatic and/or stylistic reasons. On the other hand, Curme (1980: 184) claims that the alternation between the synthetic and the analytic form depends on the number of syllables. In this way he points out that, as a general rule, monosyllabic words and a great number of twosyllable ones take the synthetic form, whereas some two-syllable words as well as those consisting of more than two syllables adopt the analytic form. Jespersen (196170: 347 ) believes that the choice is not always so clear as many authors claim and that most of the rules exhibit exceptions. As regards this distinction between synthetic and analytic gradation, Quirk et al. (1991: 461-3) argue that it depends on adjective length and they suggest the following rules: (1) Monosyllabic adjectives usually take the inflected form, although some of them follow the periphrastic way of gradation. Nevertheless, they point out that most monosyllabic adjectives accept both types of gradation; (2) Many two-syllable adjectives adopt the inflected form, although they normally present an alternative periphrastic form. The adjectives that more easily take the inflected form are those that end in an unstressed vowel, a syllabic /1/ or shwa $+r$; (3) Adjectives of three or more syllables, except those preceded by the negative prefix $-u n$, can only form the comparative according to the periphrastic form; (4) Participial forms that function as adjectives follow the periphrastic pattern.

In Old English, the comparative and superlative degrees were formed by the addition of suffixes (Gothic -iza, -oza / -ost, -ist; Old English -ra / -ost, - est > -er / -est) independently of the number of syllables. The analytic form, whose origins are rooted in the Old English construction formed by an adverb ( $m a$, bet, betst, swi por, swipost) and a past participle, appears in the thirteenth century and continues growing in importance throughout the fourteenth and fifteenth centuries, according to some authors due to French and Latin influence. 
In the Chancery documents three different types of adjectives adopt the synthetic form of gradation: (1) Monosyllabic adjectives; (2) Monosyllabic adjectives with root vowel variation; (3) Two-syllable adjectives ending in $-y$. Table 8 offers the forms of the adjectives belonging to the first group:

\begin{tabular}{|l|l|l|}
\hline Positive degree & Comparative & Superlative \\
\hline fiee & & freest \\
grete & greter / gretter & grettest \\
late & latter & last(e) \\
long & lenger & \\
poor & porer & porest \\
vtter & & vttermast / vterest(e) / utterest \\
yonge & yonger & \\
\hline
\end{tabular}

Table 9: Gradation of monosyllabic adjectives

As for the adjectives that exhibit a comparative and superlative form with a different root vowel, the only example that can be found is good - better/bettre best(e). The last group is constituted by the following two-syllable adjectives: hevy hevier, thrifty - pryftyust and ruly - (vn)ruliest.

From the examples given above, it can be inferred that the adjectives from the corpus used follow the rules suggested by Quirk et al. in reference to the use of synthetic gradation in Modern English. The ending typical of the comparative degree is -er, whereas for the superlative degree these are -est, -mast and -ust. It is noteworthy that the adjective vtter takes for the superlative two different endings, -est and -mast. This last suffix comes form Old English - $m a+-i s t o$ and, according to Jespersen (196170: 363-4), it is associated to words expressing position in time, space or a serial order.

Attention has also been paid to the different orthographic and pronunciation changes that an adjective undergoes in adopting the comparative inflection, such as the omission of a final $-e$, the substitution of a final $-y$ by a $-i$ when it is preceded by a consonant and the duplication of a final consonant when it is preceded by a stressed vowel. The last two orthographic changes are shown by the adjectives studied. As regards the change of $\langle y\rangle$ into $\langle i\rangle$, it can be noticed that $\langle y\rangle$ changes to $\langle i\rangle$ when the suffix -er is added to hevy (e.g. hevier) and also when the -est ending is added to vnruly (e.g. vnruliest). Nevertheless, in the case of the adjective thrifty, which takes the alternative form of the suffix, e.g. - ust, the final $-y$ is kept (e.g.pryftyust). As far as the duplication of a final consonant is concerned, the following examples have been found: gretter, grettest and latter. In the case of the adjective grete, the comparative form greter is also found, although there is just one example with a single consonant contrasting with the three instances of double consonants. In the superlative, the adjective late shows the contracted form last. Another important feature that must be 
mentioned is the change of the vowel $\langle o\rangle$ to $\langle e\rangle$ in the adjective long when the comparative suffix is attached to it (e.g. lenger).

These adjectives that adopt the synthetic system of gradation realise an attributive function in prenominal position (34 instances of superlative and 9 of comparative degree) in most of the cases. There is only an example of an adjective expressing superlative degree postmodifying the noun. On eight occasions the graded adjectives realise a predicative function (4 superlatives and 4 comparatives), whereas they appear as heads of nominal groups in seven cases (6 in comparative and 1 in superlative degree). Likewise, it is interesting to take into consideration the use of the comparative degree of the adjective preceded by a determiner, a construction that could be interpreted as providing a superlative meaning. These are the examples that have been found: - functioning as premodifiers: $p e$ bett $\langle e r\rangle s<e r>$ uice / pe saide latter fest of saint Martyn /pe porer partye /pe yonger Gentilman / the yonger Baillifs; - functioning as head of a nominal group: the/ pe better (4 times). Finally, it is important to point out the occurrence of an example of double gradation, formed by the confluence of the two forms of gradation, the synthetic and the analytic one, applied to the same adjective (e.g. oure most grettest erthly comfort).

It would appear, then, that the use of the synthetic form of gradation in the Chancery texts does not essentially differ from present-day English use, although Barber (1976: 202) states that the Early Modern English comparative system is characterised by the use of suffixes with polysyllabic words and with two-syllable adjectives, which in Modern English take the analytic form (such as those ending in $-c t$, -ed, -ent, -ful, -ing and -ous) as well as by the acceptance of the double gradation.

\section{Syntactic Structure of the Adjectival Group}

The study of the adjectival group as a syntagmatic structure has been largely ignored. Mustanoja (1960), offers an account of the historical development of the different parts of speech. His study of the adjective is restricted to a description of its morphology, the inflection and the synthetic gradation, although he mentions some syntactic features, such as the fact that some adjectives govern dative or genitive case or that some adjectives govern infinitives. Likewise, Fisher, Richardson and Fisher (1984) point out some characteristic features of the adjective in the Chancery texts, but they mostly concern their morphological structure. It is also important to take into consideration the existence of other works in which the adjective is not studied as an independent category but as an integral part of the nominal group. With regard to this question we can mention The Cambridge History of the English Language (1992, vol.II). In the part of this book devoted to the syntactic structure of Middle English, Fischer deals with the adjectival group with reference to its modifying function and to the position within the nominal group. 
Thus, this study seeks to contribute to a better understanding of the syntagmatic structure of the adjectival group in Late Middle English. This section will then be concerned with an analysis of the way adjectives are modified (3.1) and the complements they may take (3.2). It will be suggested that the modification of an adjective is realised by means of intensifying adverbs (3.1.1), grading adverbs (3.1.2) and quantifiers (3.1.3), whereas the qualification is expressed through the second element of comparison (3.2.1), prepositional groups (3.2.2), infinitival clauses (3.2.3) and subordinate that-clauses (3.2.4).

\subsection{Modification}

The distinction established in this article between modification and qualification has been taken from Downing and Locke (1992). These authors claim that the adjectival group is composed of three structural elements: the head, the modifier and the qualifier. They argue that it is better to talk about modification and qualification, instead of premodification and postmodification, because the type of information provided by pre-head and post-head constituents is quite different. According to these authors, a modifier is a constituent that provides intrinsic or inherent information about the head, whereas a qualifier is that part of the adjectival group that gives extrinsic or non-inherent information of the head.

As has already been mentioned, three different types of adjective modifiers have been found in the Chancery texts:

\subsubsection{Intensifying adverbs}

\subsubsection{Grading adverbs}

\subsubsection{Quantifiers}

\subsubsection{Intensification of the adjective}

The intensifying adverbs that can be found in the Chancery texts modifying the head of an adjectival group are: al(l), all moste, best, entierly, ful(l), right [ryght, ryht, $\left.r y_{3} t, r i 3 t\right], v t t e r l y$, wel and the negative particles nat, ne, no, no(o)on, nozt, nought.

As far as the construction formed by this type of adverbs is concerned, it can be observed that the most frequent structure is that in which the adjective is modified by a single adverb that precedes it. The most common adverb is wel that occurs one hundred and seventy four times in combination with the adjective beloued, with which it forms a single word on one hundred and seventy two occasions. Likewise, there is an example of this adverb functioning as a modifier in the superlative degree (e.g. bestbeloued). Among the most frequent intensifying adverbs, it is also interesting to comment on the use of right, which occurs one hundred and fifty seven times, modifying in the majority of the examples an adjective that realises an attributive 
function (there is only one example of predicative function: hit is right nedeful for me to haue certaine $p<$ er > sonnes (P3)). In one hundred and forty four instances out of the total number of occurrences, the adverb right modifies a single adjective (e.g. right gracious lord (C3)). It is only on thirteen occasions that this adverb modifies two or three adjectives in paratactic relationship (e.g. the right heigh and myghty $p<r i>n c e$ (P4) / hys ry 3 t worthy wise \& discrete Counsell (C2)). One word combinations of this adverb with the adjective that is modified can be found in rightwys( $e$ and rightwose. Similarly, the adverb full premodifies an adjective realising an attributive function twenty one times and twice an adjective in predicative function (e.g. their full grete hurt (C4) / the which to $h i<m>$ is ful hevy (P3)). Like the other adverbs previously mentioned, full can be joined to the modified adjective, as is shown in fulworshipfull, fultrusty and fulnotable. The rest of the intensifying adverbs that have been mentioned above are of a very low frequency. It is noteworthy that the most frequent adverbs in the Chancery texts (wel, right and full) are seldom used in present day English. In Modern English, the adverb well normally functions as a clause constituent (e.g. She did well), being rarely found as a group constituent (e.g. she was well aware of the problems). The adverbs right and full have been replaced by very. In relation to the negative adverbs, it is important to mention the fact that their use as modifiers is not at odds with the use of negative adverbs at the level of the clause, since the phenomenon of double negation was very frequent (e.g. it nys nozt couenable ne fittyng to be to pe plesir of god ne of pe world (C3)).

Although, as has already been mentioned, the most common structure is that in which a single adverb modifies the head of the adjectival group, examples of recursive modification can be found. This construction is formed by the negative particle nought, preceding the adjective, and the comparative adverb ynow, following it (e.g. pe saide so $<m>m e$. and assignement nought suffeceant ynow (C2)). Likewise, in the Chancery texts it is possible to find adjectival groups in which the adverb that is modifying the adjective is at the same time modified by an adverb. This phenomenon, observed, for instance, in right welbeloued (Cosin) (P3) is referred to as submodification by Angela Downing and Philip Locke (1992). These authors also make reference to the concept of sub-submodification, that can be exemplified with a construction found in the Chancery texts formed by the combination [right + entierly] + [wel-/best-] (e.g. my right entierly welbeloued cosyn (P3)). Nevertheless, it must be pointed out that these two phenomena are of little productivity in the Chancery documents, as they still are nowadays.

\subsubsection{Gradation of the adjective}

This section is devoted to the analysis of analytic gradation in the Chancery texts, that is, to the type of gradation realised by grading adverbs. Depending on the type of grading adverbs, the following degrees of comparison can be distinguished: 
3.1.2.1. Equality, by means of the correlation als / as / as well . . as

3.1.2.2. Sufficiency or excess, by means of so ... (that)/such . . (as) / to / ynow

3.1.2.3. Superiority, by means of more

\subsubsection{Superlative, by means of mo(o)st}

No occurrence of comparative structure of inferiority has been found in the group of texts considered for this study.

It is important to notice that, in this section, attention will be paid only to the part of the comparative structure that functions as modifier, that is, the standard of comparison. The second element of comparison, that element with which the comparative relation is established, will be analysed as part of the qualification of the adjective.

\subsubsection{Comparison of Equality}

In Old English, the relationship of equality was normally expressed by means of the construction swa . . swa (e.g. swa beorht swa gold), in which the first swa was frequently reinforced by eall (e.g. seo beorhtnys is ealswa eald swa pat fyr). In Middle English ealswa ... swa appears as also ... so and later on as so . . as or as . . . so (e.g. pou pei weren also trewe so er was tre or ston). Ealswa (alswa) ceases to be characterised by its emphatic nature and becomes an equivalent form for swa (e.g. alse muchel ase heo ever con). ${ }^{7}$

In the Chancery documents, the relationship of equality is expressed by means of the correlation as ... as (e.g. with as goude hert \& wyll as eny man pat lyuith (N2)). The use of some variant forms of as such as als (developed from ealswa > also) or aswel( $l$ ) and as well as is less frequent, and they also appear in correlation with the second element of comparison introduced by as (e.g. in als humble maner as $i$ (c)an or may (C3)).

\subsubsection{Comparison of Sufficiency and Excess}

In their contemporary English grammar, Quirk et al. (1991) comment on a type of syntactic structure that they refer to as comparison of sufficiency or excess. According to these authors, this type of structure combines the concepts of sufficiency or excess with the notions of purpose or result. They distinguish two different types of constructions: on the one hand, that introduced by the adverbs enough and too in correlation with an infinitive clause and, on the other hand, the one introduced by so and such that can be followed by a that-clause functioning as correlative element.

7. The examples have been taken from Mustanoja (1960: 278). 
In the Chancery texts, the most frequent comparative adverb that establishes a relationship of sufficiency with the adjective it modifies is $s o(o)$, which requires the use of the conjunction that in fifteen of its occurrences in order to introduce the second element of comparison (e.g. the cas is so grete $p<a>t$ ye ne couthe not ymagyn hit gretter (S1)). In the remaining five contexts in which it occurs, so(o) introduces a comparative relationship that does not exhibit a correlative element (e.g. This so nedeful and meritorious work may come to gode effecte (P3)). Less frequent is the use of such (only six instances were found), which can appear with a correlative clause introduced by as (e.g. with ynne suche a c<er>tain day as ye shal li(mit) (S2)) or without explicit second term of comparison (e.g. in Eschewyng of such horrible mourdurs in tyme comyng (C3)). It is important to point out that such only modifies adjectives realizing an attributive function, as in present day English, whereas so can also modify adjectives in predicative function. Likewise, a parallelism with Modern English can be established in relation to the position adopted by so and such when they precede the indefinite article, since so precedes the article in combination with the adjective (e.g. so grete a multitude (N2)) whereas such is separated from the adjective (e.g. suche a c<er>tein day (S2)), which coincides with the common practice nowadays. The sufficiency degree is also expressed by means of ynow, which appears once, placed after the adjective that is modified (e.g. pe saide so $\langle m>m e$. and assignement nought suffeceant ynow (C2)).

There is just an example of a construction expressing comparison of excess and it is introduced by the adverb to (e.g. pe forsaid $p<e r\rangle$ son is holden to besy in such mat<er>s (S1)).

\subsubsection{Comparison of Superiority}

In Old English, the analytic form of gradation was very rare, it was exclusively found in constructions formed by the adverbs ma, bet, betst, swipor and swipost. Curme (1980) states that the analytic form of gradation by means of more and most, which is due mainly to French influence, emerges in the thirteenth century and reaches its greatest productivity in the sixteenth century.

In the texts under analysis it can be observed that the use of the analytic form in order to express the superiority degree is not very common. The comparison of superiority is expressed by means of the adverb more, which modifies two-syllable adjectives, such as pleine and heynouse, as well as polysyllabic ones, such as substancial, horrible, haboundaunt and euident. It is important to notice that in three cases this comparative adverb is preceded by an article or personal pronoun that provides a superlative meaning to the structure (e.g. pe more pleine knowleche of pe trouthe (S1)). Nowadays the superlative form is preferred in this context, although the comparative of superiority form can be occasionally found. 


\subsubsection{Superlative}

As regards the analytic form of superlative degree, it is interesting to point out that, even though it was almost non-existent in Old English and it gradually started to grow in importance during the fourteenth and fifteenth centuries, in the Chancery texts this type of construction is quite frequent. It can be found not only with polysyllabic adjectives but also with two-syllable and monosyllabic ones. Among the monosyllabic adjectives that are modified by the superlative adverb most, the occurrence of adjectives such as high, wise or sad, that in Modern English normally take the synthetic form of gradation, can be mentioned. Although Quirk et al. claim that most of the monosyllabic adjectives allow both forms of gradation, it is noteworthy that there is not a single example in the corpus of these adjectives adopting the synthetic form. Likewise, it is interesting to comment on the use of the analytic form of gradation with some twosyllable adjectives that Quirk et al. classify among those that in Modern English favour the addition of comparative suffixes, such as those ending in -y (e.g. douty, worthy) and in -le (e.g. humble, noble), although it is also used with two-syllable adjectives that are not usually graded synthetically, as those ending in -ous (e.g. famous, gracious). Finally, it is important to mention the occurrence of an example of double gradation in which the adverb most modifies a monosyllabic adjective that exhibits the superlative suffix (e.g. our most grettest erthly comfort (C3)).

Tables 9 and 10 below offer the distributions of the comparative and superlative degrees in relation to the form, synthetic or analytic, they adopt:

\begin{tabular}{|l|c|c|c|c|}
\hline Comparative & Monosyllabic & Two-syllable & Polysyllabic & Total \\
\hline Synthetic & 18 & 1 & & 19 \\
& $94.74 \%$ & $5.26 \%$ & & $100 \%$ \\
\hline Analytic & - & 3 & 4 & 7 \\
& & $42.86 \%$ & $57.14 \%$ & $100 \%$ \\
\hline Total & 18 & 4 & 4 & 26 \\
& $69.24 \%$ & $15.38 \%$ & $15.38 \%$ & $100 \%$ \\
\hline
\end{tabular}

Table 9: Synthetic and analytic comparative forms

\begin{tabular}{|l|c|c|c|c|}
\hline Superlative & Monosyllabic & Two-syllable & Polysyllabic & Total \\
\hline Synthetic & $\begin{array}{c}39 \\
95.12 \%\end{array}$ & $4.88 \%$ & - & 41 \\
& 10 & 40 & & $100 \%$ \\
\hline Analytic & $13.7 \%$ & $54.79 \%$ & $31.51 \%$ & 73 \\
& 49 & 42 & 23 & $100 \%$ \\
\hline Total & $42.98 \%$ & $36.84 \%$ & $20.18 \%$ & $100 \%$ \\
\hline
\end{tabular}

Table 10: Synthetic and analytic superlative forms 
From this it follows that the synthetic gradation prevails over the analytic type in the case of monosyllabic adjectives, whereas in relation to two-syllable and polysyllabic ones the analytic form is overwhelmingly preferred.

\subsubsection{Quantification of the adjective}

Downing and Locke (1992) mention that the quantification of the adjective takes place with adjectives that express length, depth, height and age. In the Chancery texts two quantified adjectives have been found: one expressing weight, hevy, and the other expressing value, worth, notions that are not mentioned by these authors but that can be equally found in Modern English. Likewise, it can be noticed that this type of modifier can precede or follow the adjective, as is also common in present-day English (e.g. every pounde weighte is half an vnce hevier thanne the pounde of the seide estandarde (C3) / whiche godes were worth: l. li. (C3)).

\subsection{Qualification}

In the structure of the adjectival group, the following linguistic units can be found realising the function of head qualifier:

\subsubsection{Second element of comparison}

\subsubsection{Prepositional Groups}

\subsubsection{Infinitive clauses}

\subsubsection{Subordinate that-clauses}

\subsubsection{Second Element of Comparison}

Adjectives that have been modified by grading suffixes or adverbs can be qualified by the second element of comparison realised by different linguistic units, depending on the comparison degree that is expressed.

\subsubsection{Comparison of Equality}

The qualification associated to the comparative particle $a(l) s \ldots$ is realised by a clause introduced by ... as. In the Chancery documents ten instances of this construction can be found (e.g. in als humble maner as $i$ (c)an or may (C3)). It is interesting to mention the occurrence of an adjective in comparative degree that is qualified by two different elements (an adverb and a clause) introduced by as (e.g. as grete as euu $\langle r\rangle$ pey were (as) whan pe Cyte of people \& goud stovde most in prosp $<$ er $>$ ite $(\mathrm{N} 2)$. 


\subsubsection{Comparison of Sufficiency or Excess}

Among the comparative particles of sufficiency or excess (so, such, to and ynow), only those adjectives premodified by so and such are qualified in the Chancery texts. It can be observed that fifteen adjectives that are graded by the adverb so are qualified by a clause introduced by the conjunction that (or pat) (e.g. the cas is so grete $p<a t>$ ye ne couthe not ymagyn hit gretter (S1)). However, in the case of four adjectives that are modified by such, it can be seen that the second element of comparison is realised by a clause introduced by as (e.g. for hit is oure wille pat he (haue) suche l<ett>res patentes as may be vaillable (and resonable) to him in pis caas (S1)). Quirk et al. (1991: 1144) consider this use to be formal and archaic and they point out that in Modern English the most frequent construction is that introduced by the conjunction that, which can be omitted in informal style.

As far as the other particles (to and ynow) are concerned, it can be said that whereas in the Chancery texts they do not present any correlative form functioning as qualifier, in Modern English they are frequently followed by an infinitive clause that can contain its own subject introduced by the preposition for.

\subsubsection{Comparison of Superiority}

Those adjectival groups in which the modifier is realised by the comparative adverb more in the analysed texts present a qualifier introduced by than (also thanne, thenne, them and yan) (e.g. a gretter so $<m>m e$ thenne the so $<m>m e$ of the dette 3 (C4)). In the Chancery documents there is no example of a qualifier introduced by of in correlation with the comparative more, a construction that can be found in present-day English.

\subsubsection{Superlative}

Quirk et al. (1991) point out that the possible realisations of the second element in a superlative structure are a relative clause and a prepositional group introduced by of in Modern English. These two constructions are the ones that can be found in the Chancery texts, with the first one being the most frequent (eight occurrences) (e.g. in the most secret wyse that pei coude: (P4); the freest Knyght or Squyre of the Rewme (C1)). Likewise, it must be mentioned that there is an example of qualification introduced by as, a realisation that is not found in Modern English (e.g. in the best wyse as longeth vn to hym in this cas (S1)).

It could be claimed that, as regards the qualification of the adjective realised by the second element of comparison, the Chancery documents present structures that are, in most cases, identical to those characteristic of Modern English.

\subsubsection{Prepositional Group}

An adjective can be qualified by a prepositional group introduced by different prepositions that are governed by the adjective functioning as head of the adjectival 
group. The prepositions that can be found in the analysed texts together with the adjectives that they qualify are the following:

- To: accept, auaillable, behouefull, best, contrarie, couenable, due, expedient, fauorable, hevy, honourable, lawful, leful, necessary, preiudiciel, resonable, suffeceant and vaillable.

- In: auaillable, besy, dere, effectuell, fauorable, free, gilty, parciall, stronge, voide and welbeloued.

- Of: $\quad$ contagious, defesable, desolat, destitute, gilty, priue, saf, voyde and worthi.

- For: behoveful, necessarie, nedeful, redy, resonable, sufficient and vaylable.

- Vnto: expedient, preiudiciel and vaillable.

- Be: $\quad$ blessed.

Although, as a general rule, each adjective governs the use of a certain preposition, there are occurrences in which an adjective is qualified by a prepositional group that can be indiscriminately introduced by two or more different prepositions. Thus, for instance, it could be mentioned that the adjective behoueful can be qualified by a prepositional group introduced by to or by for (e.g. shalbe behouefull and necessary to hym to be had (C4); byn behovefull and necessarie for hym (C4)). This phenomenon can also be seen in the following adjectives: necessarie (to (1); for (3)), resonable (to (1); for (1)), sufficient (to (1); for (8)) and uaillable (to (1); for (1)), the last adjective being also qualified by a prepositional group introduced by vnto. Other adjectives show an alternation between to and vnto, such as expedient and preiudiciel, or between of and in, such as gilty.

Likewise, two adjectives in the analysed texts present two qualifiers introduced by different prepositions but, in this case, the change of preposition implies a different interpretation, since one of the qualifiers would be an argument and the other one an optional element (e.g. fauorable to him yn pis mat<er>e (S2)).

The prepositional group that qualifies the head of an adjectival group occurs most of the time in postposition to the adjective. However, four examples in which the prepositional group precedes the adjective have been found (e.g. to the seid office due (C4)). ${ }^{8}$

As regards the function realised by the adjectives qualified by a prepositional group, it can be argued that in most cases they realise a predicative function (43 instances), and less frequently an attributive function (10 occurrences in postposition; 5 in preposition).

8. The other three examples are: to hem couenable and expedient (C3); to hi $\langle m\rangle$ is ful hevy (P3); to hym auaillable $(\mathrm{C} 4)$. 
In their grammar of Contemporary English, Quirk et al. (1991) offer a list of prepositions that can introduce an adjective qualification. Among the most frequent ones, they point out about, at, from, of, on/upon, to and with, for and towards being less frequently used. This list does not coincide with what is found in the Chancery texts, since there are just to and of, from the first group, and for, from the second group. Likewise, the occurrence of other prepositions as qualifiers of the adjectival head (in, vnto and be), which are not mentioned by these authors, must be noticed.

\subsubsection{Infinitive Clauses}

The adjectival groups in which the head is qualified by an infinitive clause realise in most cases a predicative function (18 examples), except for the adjective sufficeant (7 occurrences), which realises the function of noun premodifier and postmodifier, and the adjective raisounable ( 1 instance) that postmodifies a noun. The infinitive clauses are preceded by to, except for the clause qualifying the adjective leful, which is introduced by for to.

There are three contexts in which an adjective qualified by an infinitive clause and realising a predicative function can occur:

- Functioning as subject complement, in which case the subject of the main clause that contains the adjective coincides with the subject of the infinitive clause (e.g. The which mat<ers> \& ich of hem $y\langle e\rangle$ seid Robert is redy to preue $(\mathrm{C} 4))$;

- Functioning as object complement, in which case the object of the main clause coincides with the object of the infinitive clause (e.g. wighte pe seid Gieffrey hath redy to shewe by collour of heer office (C3));

- Functioning as subject complement, in which case the subject is realized by it or $\varnothing$ and the adjective is qualified by an infinitive clause that represents an example of extraposed subject (e.g. hit is right nedeful for me to haue certaine $p<e r>$ sonnes $(\mathrm{P} 3))$.

In the Chancery documents, six examples of qualification realised by an infinitive clause follow the structure: adjective + prepositional group (to/for) + infinitive clause. This construction, in which the nominal group introduced by the preposition is functioning as subject of the infinitive clause, occurs in combination with the adjectives behoueful, lawfull, leful, nedeful, necessary and sufficient.

\subsubsection{Subordinate That-clause}

The type of qualification realised by a subordinate clause introduced by the conjunction that only appears twice in combination with the adjective certain, realising a predicative function (e.g. ye ben certain pat pe bulles of oure holy fader pe pope: ben come for pe translacion of pe Bysshop (S2)). In Modern English the 
qualification of an adjective by a that-clause is much more frequent than in the Chancery documents, since different possibilities as regards the inflection of the verb can be found (indicative, subjunctive or the auxiliary should, with a putative or hypothetical meaning).

\section{Conclusions}

As far as the inflectional properties of the head of the adjectival group are concerned, this study has shown that in the first half of the fifteenth century the complex adjective inflectional system typical of Old English has developed towards a system characterised by the almost complete absence of inflection. The conclusion that emerges from a consideration of the data is that the morphological structure of the adjective in the period under analysis and, particularly, in the Chancery texts does not essentially differ from that typical of Contemporary English.

From the analysis of the syntagmatic structure of the adjectival group presented in this article, it can be concluded that an adjectival group can present the following structures:

- head

- modifier + head

- modifier + head + qualifier

- head + qualifier

In the Chancery documents the adjectives are modified by intensifying and grading adverbs and, less frequently, by quantifiers.

As regards the intensifying adverbs, it can be argued that these adverbs premodify the head of the adjectival group, except for ynow, which occurs in postposition. The most frequent adverbs are wel and right, followed by ful, adverbs that are normally attached to the noun they modify. Less common is the use of all, all most, entierly, vtterly and the negative particles.

Although the most frequent structure is that in which the adjective is premodified by a single adverb, there is one occurrence of an adjective modified by two adverbs. Likewise, some instances of submodification can be found.

As far as the modification realised by grading adverbs is concerned, four degrees have been distinguished: equality, sufficiency or excess, superiority and superlative. As has already been stated, adjectives in comparative degree of superiority or in superlative degree can take a synthetic or an analytic inflection. The following conclusions, common to the different documents and periods, regarding the use of one or the other form of comparison can be established: 
- Monosyllabic adjectives prefer the synthetic form for the comparative (18 examples of synthetic / 0 analytic) as well as for the superlative (39 synthetic/ 10 analytic).

- In the case of two-syllable adjectives the analytic forms dominate in the comparative ( 1 synthetic / 3 analytic), as well as in the superlative ( 2 synthetic/ 40 analytic).

- In all the instances of polysyllabic adjectives, the analytic form of comparison is observed.

As for the quantification of the adjective, it can be said that it is realised by a quantity expression in pre- or postposition.

As can be deduced from the syntactic structures of the adjectival group mentioned above, two different types of qualification could be distinguished:

- Qualification of modified adjectives, in which the type of qualifier is governed by the type of modifying adverb

- Qualification of non-modified adjectives.

With regards to the qualification that is dependent on modifying adverbs, the following relations could be found in the Chancery documents:

- qualification correlative to the comparative adverbs of equality: a clause or an adjective introduced by ... as.

- qualification correlative to the excess or sufficiency degree: a subordinate clause introduced by that, in parallel construction with so, and introduced by $a s$, in the case of such. Two modifying adverbs (to and ynow) occur without an actualised second element of comparison.

- qualification correlative to the comparative of superiority: than.

- qualification correlative to the superlative degree: in most of the cases it is introduced by than, less frequently by of and as.

The type of qualification that is independent of the adjective modifiers is realised by:

- prepositional groups, introduced by the prepositions to, in, of, for, vnto and be (arranged by order of frequency). It was found that an adjective could be qualified by different prepositions, implying sometimes different interpretations.

- an infinitive clause, introduced by (for) to, which can share the subject of the main clause when the adjective is realising a predicative function. Likewise, in predicative function, the subject of the infinitive clause can be introduced explicitly by to or for, when the infinitive clause is functioning as extraposed subject of the main clause. 
- a subordinate clause, introduced by that. This is not a very common realisation since it occurs only in combination with the adjective certain.

Finally, it is worth mentioning that qualified adjectives realise, as a general rule, a predicative function. They very rarely occur in attributive function, a case in which they prefer postposition. When a qualified adjective is premodifying a noun, its qualifier generally occurs after the noun, giving place to what is known as a discontinuous adjectival group (Downing and Locke 1992: 537).

It could be stated that, as far as the syntagmatic structure of the adjectival group is concerned, the language of the first half of the fifteenth century and, specifically, of the Chancery documents, does not differ to a great extent from that of Modern English. Therefore, it could be claimed that the Chancery documents are of great importance, not only because they constitute the earlier use of English for official writings, but also for their contribution to the development of Modern Standard English.

\section{Works Cited}

BARber, Charles. 1976. Early Modern English. London: André Deutsch.

Blake, Norman, ed. 1992. The Cambridge History of the English Language. Volume II: 1066-1476. Cambridge: C.U.P.

Curme, George O. 1980-83 (1935). A Grammar of the English Language. 2 Vols. Essex, Connecticut: VERBATIM.

Downing, Angela and PhiLIP Locke. 1992. A University Course in English Grammar. New York: Prentice Hall.

ExPÓSITO GONZÁLEZ, Ma CRUZ. 1996. La estructura del sintagma nominal en el inglés de la Cancillería: 1400-1450. Barcelona: Kadle Books.

FISCHER, Olga. 1992. "Syntax". In Norman Blake, ed. The Cambridge History of the English Language. Volume II: 1066-1476. Cambridge: C.U.P. 207-32.

FISHER, JoHN H. 1977. "Chancery and the Emergence of Standard Written English in the Fifteenth Century". Speculum 52: 870-99.

—. 1979. "Chancery Standard and Modern Written English". Journal of the Society of Archivists 6.3: 136-44.

Fisher, John H., Richardson, Malcolm And Jane L. Fisher, eds. 1984. An Anthology of Chancery English. Knoxville: The University of Tennessee Press.

Hughes, Susan EILEEN S. 1980. "Guildhall and Chancery English". Guildhall Studies in London History 4.2: 52-62.

JesPersen, Отto. 1961-70 (1909-49). A Modern English Grammar on Historical Principles. 7 Parts. London: Allen \& Unwin Ltd.

Kruisinga, E. 1932 (1911). A Handbook of Present-Day English. 5th ed. Part II, 2 and 3. Groningen: P. Noordhoff. 
LASS, Roger. 1992. "Phonology and Morphology". In Norman Blake, ed. 1992. The Cambridge History of the English Language. Volume II: 1066-1476. Cambridge: C.U.P. 23-155.

LEKEBUSCH, JuLIUS. 1906. Die Londoner Urkundensprache von 1430-1500: ein Beitrag zur Entstehung der Neuenglischen Schriftsprache. Halle A.S.: Max Niemeyer.

MoRSBACH, LORENZ. 1888. Ueber den Ursprung der Neuenglischen Schriftsprache. Heilbronn: Henninger.

Mustanoja, Tauno F. 1960. A Middle English Syntax. Part I. Helsinki: Société Néophilologique.

PÉREZ Quintero, Ma Jesús. 1994. El sintagma adjetival en la lengua documental de la cancillería inglesa en la primera mitad del siglo XV. Memoria de Licenciatura Inédita. Universidad de La Laguna.

Poutsma, H. 1904-1916. A Grammar of Late Modern English. 2 Parts. Groningen: P. Noordhoff.

Quirk, Randolph, Greenbaum, Sidney, Leech, Geoffrey and Jan Svartvik. 1991 (1985). A Comprehensive Grammar of the English Language. London: Longman.

Richardson, Malcolm. 1980. "Henry V, the English Chancery, and Chancery English". Speculum 55.4: 726-50.

—. 1984. "The Dictamen and its Influence on Fifteenth-Century English Prose". Rhetorica 2.3: 207-26.

Samuels, Michael L. 1963. "Some Applications of Middle English Dialectology". English Studies 44: 81-94.

—. 1972. Linguistic Evolution. Cambridge: C.U.P.

-. 1981. "Spelling and Dialect in Late and Post-Middle English Periods". In Michael Benskin and Michael L. Samuels, eds. So Meny People Longages and Tonges. Philosophical Essays in Scots and Mediaeval English Presented to Angus McIntosh. Edinburgh. 43-54. 